\title{
Mobile Assisted Language Learning: Platfoms To Support Students Teacher Improving Reading Skill
}

\author{
Prativi Khilyatul Auliya* \\ Universitas Muhammadiyah Gresik, Indonesia \\ prativi.auliya@umg.ac.id \\ Tri Yuli Ardiyansah \\ Universitas Muhammadiyah Gresik, Indonesia \\ ardi13@umg.ac.id \\ Ribeh Najib Muhammad \\ Universitas Muhammadiyah Gresik, Indonesia \\ ribeh@umg.ac.id
}

\begin{abstract}
This study was investigating the platforms on Mobile Assisted Language Learning (MALL) that mostly used by students teachers on first and second year to improve their reading skill. Qualitative research design which used questionnaire and interview was employed to gain and analyze the data. The result showed that $79.3 \%$ students benefited various platforms, while the rest never used any platforms to support improving their reading skill. The top-five platforms were; (1) Wattpad, (2) Social Media, (3) Duolingo, (4) U-Dictionary, and (5) Quora. Students favored those platforms due to its popularity, attractiveness, efficiency, and benefit. The up-to-date and popular platform such as various social media and Quora were used to improve reading skill by connecting them to communicate to English native. Attractive platform such as Wattpad, where they could read countless stories was demanded to please their soul of readers. The efficient ones, Duolingo and U-Dictionary were chosen by them who prefer to learn in organized way. Fortunately, all of those platforms offered advantages for students such as improving their vocabulary acquisition, grammar competence, reading speed, and reading comprehension as well.
\end{abstract}

Keywords: MALL; online platform; reading; autonomous learner

\section{Introduction}

Not all students teacher who joined English Education Department are possessing good English skills. In some occasions, the students teacher choose English Education Department because they already have good English skills, then they want to be an English teacher. However, some others do not have any good English skills, so they decided to take English Education Department to increase their English skills to become a teacher later on. This kind of students teacher seek new knowledge and need to practice a lot to master a good English skills. They tend to rely on lecturers who provide them with some courses that could improve their skills significantly. Unfortunately, the lecturers could not help and monitor them during 24 hours. That is why these students teacher should be autonomous learners. These typical students teacher need more efforts compared to students' teacher who already have good English skills.

To be autonomous learner, students teacher are strongly suggested to be able to set their own goals, identify and develop learning strategies, select relevant learning sources and appropriately assess their learning performance (Chan, 2001). Students teacher have to know their need, which is seen as skill that they are not mastering yet. When they already know their own needs, they will be easier in finding learning resources and media that could possibly help them to overcome their problem. As autonomous learners, students teacher could choose the most appropriate learning resources, media, time and place where they will learn. Luckily, students teacher can learn everywhere and anytime easily by using technology in the recent days. Gadget and internet are two things that really support autonomous learning. 
One of sophisticated technology that can be used to support autonomous learning is mobile phone. Now days, mobile phone is not only for communication matter anymore, it is also for the purpose of learning. Students teachers' live is dominated by mobile phone since it fits into students' pocket and nearly always on. Moreover, due to its flexibility, low cost, small size and user-friendliness, mobile phone can be benefitted to support language learning. This phenomenon is called as Mobile Assisted Language Learning (MALL). Mobile phone can access and operate various applications that support students teacher's autonomous learning, including listening, speaking, writing, and also reading.

Reading, one of receptive skills, is demanded to be mastered by students teacher because they could get information to support their productive skills through reading. Mark Clarke and Sandra Silberstein (1977) in Brown (2000) stated that reading skill depends on the efficient interaction between linguistic knowledge and knowledge of the world. Grammar competence and vocabulary mastery are two among linguistic knowledge that required to be learnt during reading. Students teacher need to comprehend the vocabulary in order to understand what the reading text said. Moreover, understanding grammar is another point to comprehend the text. Having background knowledge is also important thing to put in mind to grasp the writer's intention on the text. These complex skills make reading quite hard to master.

These demands make students teacher have to be smart in choosing appropriate MALL application or website to support their autonomous learning. Many studies (Qing, 2016; Hazaea and Alzubi, 2018; Butarbutar, 2019; Rakhmawati, 2019; Hernadijaya, 2020 and many more) have discussed the impacts of using MALL to support autonomous learning and teaching-learning activities, however, still less in explaining the details of applications or websites that mostly recommended by students. This current study is really needed to accommodate students teacher's recommendation on MALL applications and websites that could support autonomous learning, especially in reading skill. By knowing the details of recommended MALL applications and websites, educators and students teacher could utilize them to gain benefits, to learn reading skill independently. Therefore, this research investigates (1) what applications that mostly used by students teacher of English Education Department to improve their reading skill? and (2) why do they choose that applications to learn independently as autonomous learners?

\section{Autonomous Language Learning}

Many scholars have attempted to define learner autonomy; nevertheless, no consensus on the definition has arrived until today. However, Holec's (1981) definition is the most cited in the literature. He defines learner autonomy (LA) as 'the ability to take charge of one's own learning'. It means that learners or students have responsibility for themselves on all aspects of their learning, including what they are going to learn, what is the purpose of their learning, and how they will learn it. Little (1991) defines learner autonomy as the capacity of learners to learn actively in independent settings which means that students are able to learn independently without the constraints of time and place of learning. More importantly, a highly autonomous learner is claimed to be able to set their own goals, identify and develop learning strategies, to select relevant learning sources and appropriately assess his/her learning performance (Chan, 2001).

After setting learning goal(s), students have autonomy to choose their own learning strategies, media, and resources that match to their goal(s). It could mean during selecting those learning aspects, students do not get any interventions from either their lecturers or other people. Students who possibly do this one, are they who already adult and mature enough to take their decision, and need almost no help from others to decide their learning. Students could learn everywhere and anytime without limitation. In the recent days, most students take advantage of technology such as mobile devices to support their learning autonomy.

This paper subsumes these two definitions and operationalizes LA as the ability of students especially EFL students teacher to take charge of their learning in independent settings. This definition entails students are being responsible for making decisions about their learning in terms of finding out platform to support their reading skill, including the reading material, vocabulary and grammar as the supporting component of reading.

\section{Language Learning via MALL}

MALL is dealing with the usage of mobile technology for language learning. In the recent days, students teacher do not always have to learn foreign language in a classroom. They have opportunity to study using mobile devices in a place and time as they like. Moreover, the emerging of internet creates open and distance learning a means of receiving education from all parts of the world. In a very short period, the attractiveness of distance learning led to the realization that mobile devices provide effective resources for education.

The effectiveness of mobile devices compared to other devices such as laptops or computers is that mobile devices are less expensive than others. Furthermore, Huang (2010) stated that mobile devices are effective to support language learning because of its portability and connectivity. Klopfer et al., (2002) added three more characteristics of mobile devices to support language learning; social interactivity, context sensitivity, and individuality. By having those characteristics, mobile devices are suitable to be benefitted as language learning resources and media that can support autonomous learners.

As a language learning resources and media, mobile devices can be used in broad areas of language learning such as, vocabulary, grammar, reading comprehension, and many others. In vocabulary matter, Fageeh (2013) already proved that mobile devices are able to increase vocabulary learning and improve motivation for vocabulary acquisition due to their portability and access to various activities. Moreover, on another study Baleghizadeh \& Oladrostam (2010) showed that the students who benefit mobile-assisted learning have a significantly better performance on a multiple- 
choice grammar post-test. In terms of reading, intermediate students' reading comprehension ability is getting better significantly when they use mobile application (Naderi \& Akrami, 2018).

MALL could be more effective when students are equipped with certain tools, support from teachers, and technologies and materials (Kukulska-Hulme, 2016) that may lead in students taking responsibility for perceiving a new language. In addition, since EFL students need to interact and communicate in English for better learning outcomes, MALL could maintain an effective learning environment and create meaningful learning opportunities (Hazaea \& Alzubi, 2016) that promotes student-centeredness (Kim \& Kwon, 2012) and collaborative learning outside the classroom (Al-rahmi et al., 2014; Huang et al., 2009). Previous research shows that MALL affects vocabulary learning strategies, autonomy, and reading comprehension (Nosratinia et al., 2014; Zarei \& Gahremani, 2010). Technology improved autonomous learning through an English learning model that included short stories, newspaper and magazine articles, letters, and internet articles (Wang, 2010).

\section{Method}

This study employed qualitative research design to identify what application that mostly used by English Education Department students and the reasons why they choose that certain application. The subjects were 58 students teacher of the first and second year of English Education Department, Universitas Muhammadiyah Gresik. Semistructured questionnaire and interview were used as the instruments to gain the data.

\section{Findings and Discussion}

Most of students $(79.3 \%)$ experienced in utilizing online resources to support them improving their reading skill. They benefit various platforms, including applications and websites on their mobile phone. The top 5 platforms that used by students teacher are presented as follows;

Table 1. Top 5 Platforms Used by Students Teacher to Support Improving Reading Skill

\begin{tabular}{cccc}
\hline No & Platfoms & Type & Percentage \\
\hline 1 & Wattpad & Website \& Application & $26.1 \%$ \\
\hline 2 & Social Media & Website \& Application & $17.24 \%$ \\
\hline 3 & Duolingo & Website \& Application & $13.79 \%$ \\
\hline 4 & U-Dictionary & Application & $10.34 \%$ \\
\hline 5 & Quora & Application & $8.62 \%$ \\
\hline 6 & Others & Website \& Application & $8.62 \%$ \\
\hline
\end{tabular}

The first platform that favor by students is Wattpad. It is both a website and an application that can be used by its users to read as well as to share their writings. Students prefer Wattpad due to some reasons, including its benefit and attractiveness. It is attractive since it provides students with countless stories in various genres. In addition, Wattpad is efficient in term of cost. The stories on Wattpad are free of charge and could be saved, so that students are able to read the stories offline. Students could access many kinds of their favorite books without spending extra money. Students select appropriate reading resources because of its attractiveness, its language level and its interesting content (Auliya et al., 2017). When they find the appropriate one, they will be addicted to reading. Besides, Wattpad is beneficial for students who want to improve their reading skill because they can discover new vocabularies there. Some student teachers stated that they find new vocabularies and after several times opening Wattpad application, they become familiar with those vocabularies. It shows that using mobile application could increase vocabulary learning (Fageeh, 2013; Wu, 2015). By using Wattpad, students can train their reading focus too, just like student said "I like to read and improve my reading skill. I can train my reading focus too".

Social media is the second favorite platform. Students take advantages of several social media such as Instagram, YouTube, Facebook, and Twitter. Social media is favor for its popularity, attractiveness, and efficiency. It is very popular among students and cannot be separated with students' daily life. Students said that they are addicted to open and read something new on social media in order not to miss any single information. Students' vocabulary is getting increase unconsciously after reading the story, caption, and content of social media which is written in English. Moreover, reading in social media can boost students' reading speed. When students love to read anything on social media, they will read more and more, this leads to students' reading speed increase. When students are hook on reading, they will become adequate readers and acquire large vocabulary (Krashen, 2011). Furthermore, students are able to communicate with English native speakers directly through social media. By reading the massage from the native, students get authentic reading text that can improve their reading skill. Some students argued that they feel confident and their reading skill is improved a lot after using social media. That is why social media is efficient for students to learn independently. Social interactivity is coming up when students learn benefit the existence of mobile assisted language learning (Klopfer et al., 2002).

The next platform is Duolingo. It is an American platform for language learning that available as website and mobile application as well. Students stated that they like using Duolingo because most of its learning features are free of 
charge. Moreover, it is also completed by animated pictures and colorful texts that can make students interested in using it. Aside from its attractiveness, Duolingo gives a lot of benefits for students. This platform helps students to learn vocabulary and train their reading comprehension as stated by one of the student as follows; "Duolingo can help us remembering vocabulary easily and train our reading comprehension as well since there's also feature of mini story where we can read, and complete the story based on our language target". On the previous study by Herdadijaya (2020) and Ajisoko (2020), Duolingo is proved effectively improve students vocabulary. Not only vocabulary, Duolingo is effective to learn grammar. After using Duolingo, students believe that their grammar is getting better than before and the vocabulary is more varied. Understanding these two components (vocabulary and grammar) makes students easier in comprehending English text. Moreover, Duolingo provides assessment for its users. This supports students to be an autonomous learner (Chan, 2001) since they can select appropriate platform and assess their own learning.

Platform Number 4 that chosen by students is U-Dictionary. This is a mobile application to learn independently to improve reading skill. Students select this application because it could translate reading text easily and accurately compared to Google translate. Moreover, it can be used to translate written text on the picture and to translate sound as well. So, it helps students to understand the text both in oral and written easily. More importantly, its function is not only for translating or as dictionary but also as media to learn grammar and vocabulary, as stated by student, "By using $U$ dictionary we can get any vocabularies every day when we use the application for lock screen". By getting notification of new vocabulary on the phone screen, students possibly will learn and remember the vocabulary easily. The portability of using U-Dictionary (Klopfer et al., 2002) supports students to be an autonomous learner.

Quora is the last platform of students' favor. It is in the form of questions and answer website as well as mobile application where internet users can ask for and answer questions. Anyone, including native speaker of English can post either question or answer on Quora. This leads to students' experience of reading the authentic text and context. Moreover, students like using this application because they can find a lot of information in authentic context and learning new vocabulary from people around the world at the same time. This condition motivates students to read more on Quora. Once more, by utilizing MALL, Quora on this case; could be a bridge to do social interactivity (Klopfer et al., 2002).

On the other side, several students teacher (20.7\%) stated that they never used any kinds of platforms on mobile phone, including application and websites that support them in improving their reading skill. Few students argued that reading on book or printed text is much better than reading on mobile phone. Reading on mobile phone could easily make students feel tired because of the screen. Furthermore, it creates eye fatigue that can decrease students' motivation to read more (Jeong, 2012). Aside from that reason, students teacher do not benefit the online recourses since they do not know what platforms that appropriate to improve their reading skill. It shows that students teacher still need help and guidance from the lecturers to choose suitable platform to support them to become autonomous learners in improving their reading skill. Sharing among peers is needed since it could provide students with a lot of information in deciding what kind of platforms that could be benefitted. The inferiority feeling of having low reading skill is one of the reasons why students teacher are reluctant to ask for help from their friends who already benefit some platforms as an autonomous learners.

\section{Conclusion}

Majority of students teachers have benefitted mobile devices to learn independently to support improving their reading skill. They favor platforms that are popular, attractive, efficient, and beneficial. The up-to-date and popular platform such as various social media and Quora are used to improve reading skill by connecting them to communicate to English native. Attractive platform such as Wattpad, where they can read countless stories is demanded to please their soul of readers. The efficient one, Duolingo and U-Dictionary are chosen by them who prefer to learn in organized way. Fortunately, all of those platforms offer advantages for students such as improving their vocabulary acquisition, grammar competence, reading speed, and reading comprehension as well.

\section{References}

Ajisoko, P. (2020). "The Use of Duolingo Apps to Improve English Vocabulary Learning." International Journal of Emerging Technologies in Learning 15(7): 149-155.

Al-rahmi, W. M., Othman, M. S., \& Musa, M. A. (2014). The improvement of students' academic performance by using social media through collaborative learning in Malaysian higher education. Asian Social Science, 10(8), 210221. https://doi.org/10.5539/ass.v10n8p210

Auliya, P. K., Lestari, L. A., \& Suharsono. (2017). Developing Extensive Reading Materials for Secondary School to Foster Students' Reading habit. Journal of English Language and Literature, 8(3), 706-714

Baleghizadeh, Sasan \& Oladrostam, Elnaz. (2010). The Effect of Mobile Assisted Language Learning (MALL) on Grammatical Accuracy of EFL Students. MEXTESOL JOURNAL, 34(2) 
Brown, H. D. (2000). Principles of Language Learning and Teaching. New York, Longman.

Butarbutar, R. (2019). "THE STUDY IMPACT OF WHATSAPP GROUP ON CRITICAL READING SKILL." JURNAL MAGISTRA 6(1).

Chan, Victoria. (2001). Readiness for Learner Autonomy: What do our learners tell us? Teaching in Higher Education, 6(4)

Fageeh, Abdul Aziz I. (2013). Effects of MALL Applications on Vocabulary Acquisition and Motivation. Arab World English Journal, 4(4), 420-447

Hazaea, A. N. and A. A. Alzubi (2018). "Impact of Mobile Assisted Language Learning on Learner Autonomy in EFL Reading Context." Journal of Language \& Education 4(2): 48-58.

Hernadijaya, N. S. (2020). "THE USE OF DUOLINGO APPLICATION TO ENHANCE JUNIOR HIGH SCHOOL STUDENTS' ENGLISH VOCABULARY." RETAIN 8(2): 17-24.

Holec, H. (1981) Autonomy in foreign language learning. Oxford, UK: Pergamon

Huang, C. and P. Sun. (2010) "Using mobile technologies to support mobile multimedia English listening exercises in daily life". In: The International Conference on Computer and Network Technologies in Education (CNTE 2010), At: http://cnte2010.cs.nhcue.edu.tw/

Huang, Y., Jeng, Y., \& Huang, T,. (2009). An Educational Mobile Blogging System for Supporting Collaborative Learning. Journal of Educational Technology \& Society, 12(2), 163-175. Retrieved from http://www.jstor.org/stable/jeductechsoci.12.2.163

Jeong, Hanho. (2012). A comparison of the influence of electronic books and paper books on reading comprehension, eye fatigue, and perception. The Electronic Library, 30(3)

Kim, H., \& Kwon, Y. (2012). Exploring smartphone applications for effective mobile-assisted language learning. Multimedia-Assisted Language Learning, 15(1), 31-57

Klopfer, E. and K. Squire (2002). Environmental detectives: PDAs as a window into a virtual simulated world. IEEE international workshop on wireless and mobile technologies in education, IEEE.

Krashen, Stephen D. (2011). Free Voluntary Reading. Santa Barbara: Libraries Unlimited.

Kukulska-Hulme, A. (2016). Mobile assistance in language learning: A critical appraisal. In Palalas, A.and Ally, M. (eds.), The international handbook of mobile-assisted language learning. Beijing: China Central Radio \& TV University Press, 138-160.

Little, D. (1991). Learner Autonomy: Definitions, Issues and Problems. Dublin: Authentik.

Naderi, Samane \& Akrami, Azam. 2018. EFL Learners' Reading Comprehension Development through MALL: Telegram Groups in Focus. International Journal of Instruction, 11(2)

Nosratinia, M., Saveiy, M., \& Zaker, A. (2014). EFL learners' self-efficacy, metacognitive awareness, and use of language learning strategies: how are they associated? Theory and Practice in Language Studies, 4(5), 10801092. https://doi.org/10.4304/ tpls.4.5.1080-1092

Qing, X. (2016). "A Brief Study on English Autonomous Learning Ability Based on Mobile Learning in EFL Curriculum " JOURNALS A-Z 12(11): 114-118.

Rakhmawati, I. (2019). Promoting Autonomous Learning Through Mobile Applications in a Blended English Language Classroom International Conference on English Language Teaching (ICONELT), Atlantis Press. 434. 
Wang, J. (2010). How to develop college students' autonomous English learning skills-take reading course in jointprogram in HCFT as an example. English Language Teaching, 3(3), 221-228. https:// doi.org/10.5539/elt.v3n221

Wu Q (2015) Pulling Mobile Assisted Language Learning (MALL) into the Mainstream: MALL in Broad Practice. PLoS ONE 10(5): e0128762. https://doi.org/10.1371/journal.pone.0128762

Zarei, A., \& Gahremani, K. (2010). On the relationship between learner autonomy and reading comprehension. TELL, $3(10), 1-20$ 